\begin{tabular}{|l|l|l||}
\hline \multicolumn{2}{|c|}{ PublisherInfo } \\
\hline \hline PublisherName & $:$ & BioMed Central \\
\hline \hline PublisherLocation & $:$ & London \\
\hline \hline PublisherImprintName & $:$ & BioMed Central \\
\hline \hline
\end{tabular}

\title{
Transcriptional regulation of the cell cycle
}

\begin{tabular}{||l|l|l||}
\hline \multicolumn{2}{|c|}{ ArticleInfo } \\
\hline \hline ArticleID & $:$ & 4290 \\
\hline \hline ArticleDOI & $:$ & $10.1186 /$ gb-2001-3-1-reports0004 \\
\hline \hline ArticleCitationID & $:$ & reports0004 \\
\hline \hline ArticleSequenceNumber & $:$ & 22 \\
\hline \hline ArticleCategory & $:$ & Paper report \\
\hline \hline ArticleFirstPage & $:$ & 1 \\
\hline \hline ArticleLastPage & $:$ & 4 \\
\hline \hline & & RegistrationDate : 2001-11-12 \\
ArticleHistory & $:$ & Received \\
& $:$ OnlineDate \\
\hline \hline ArticleCopyright & $:$ & BioMed Central Ltd2001-12-12 \\
\hline \hline ArticleGrants & $:$ & \\
\hline \hline ArticleContext & $:$ & 130593311 \\
\hline \hline
\end{tabular}




\section{Abstract}

Analysis of the regulation of the yeast cell cycle by nine cell-cycle transcriptional activators

\section{Significance and context}

The yeast cell cycle has been thoroughly investigated, leading to the identification of approximately 800 genes that are expressed during the cycle in a periodic fashion. It was, however, unclear how these genes are regulated. Studies based on a smaller subset of cell-cycle genes identified the protein complexes MBF (Mbp1 and Swi6) and SBF (Swi4 and Swi6) as controlling genes expressed in late G1 phase of the cycle, the protein $\mathrm{Mcm} 1$ regulating late $\mathrm{G} 2$ and some M/G1 genes, and the complex of Swi5 and Ace 2 regulating genes expressed at the end of $\mathrm{M}$ and in early G1 phase. A fundamental question not answered by previous studies is how these transcriptional regulators of the cell cycle are themselves regulated. This is the question addressed by Simon et al.

\section{Key results}

Simon et al. have determined that, during the cell cycle, the promoters of 213 genes were bound by the nine transcription factors analyzed. There was a clear difference between some of the factors as to the time of activity: for example, Swi5 acts in M/G1 and Ndd1 in G2/M, but factors such as Fkh1 showed no clear boundary of activity. From results that showed which transcription factors were bound to which promoters, it was clear that gene regulation was not a result of a single factor but of interactions between factors.

SBF regulates genes involved in morphological changes - for example, chromatin state, cell-wall growth, budding and cytokinesis - such as histone genes (HTA1-3, HTB1-2 and HHO1), genes for cellwall proteins (SCW4,CIS3, CWP1, MSB2), budding proteins (GIC2, BUD9, RSR1, CRH1), and enzymes involved in cell-wall synthesis (OCH, MNN1, GLS1, KRE6, GAS1, PSA1). In contrast, MBF mainly regulates genes involved in DNA replication and repair ( $R N R 1, R A D 27, C D C 21, I R R 1, M C D 1$, DUN1, MCM2, CDC45). Fkh1 binds to genes regulating histones and telomeres (TEL2, HHF1). Mcm1 can bind genes on its own or together with Fkh2 and Ndd1. Depending on the interactions it makes, it either regulates genes that allow transition through the cell cycle or regulates genes involved in mating 
and formation of the prereplication complex. Swi5 is important in the late stages of cell division to activate cell-wall synthesis.

The authors conclude that SBF (Swi4 and Swi6) and MBF (Mbp1 and Swi6) both regulate Ndd1, which is essential for formation of complex with Mcm1 and Fkh2 to activate the genes at G2/M. This complex then regulates Ace 2 and Swi5. Mcm1 does not act only on promoters of G2/M genes but it also activates genes in M/G1 phase. In fact, Ace2, Swi5 and Mcm1 all activate CLN3 (encoding cyclin 3); cyclin 3 binds to Cdc28, which is able to activate SBF and MBF in late G1.

\section{Methodological innovations}

Yeast strains expressing Myc-tagged cell-cycle regulators Mbp1, Swi4, Swi6, Mcm1, Fkh1, Fkh2, Ndd1, Swi5 and Ace2 were used. Proteins bound to DNA were crosslinked to the DNA with formaldehyde in vivo, the cells disrupted and the DNA sheared by sonication. DNA crosslinked to protein was then immunoprecipitated using anti-Myc antibody. After removing the crosslinks, the DNA was amplified using ligation-mediated PCR (LM-PCR) and fluorescently labeled in the same step using Cy5 dye. A control hybridization sample consisted of DNA not enriched by immunoprecipitation and labeled with $\mathrm{Cy} 3$ dye. Hybridization was carried out on microarrays containing yeast intergenic sequences.

\section{Links}

A listing of the complete set of genes bound to the nine transcription factors and additional analysis are available via Serial Regulation of Transcriptional Regulators in the Yeast Cell Cycle.

\section{Conclusions}

Simon et al.identified a set of promoters bound by each of the transcription factors, which enabled identification of the consensus binding sites. They also describe how expression analysis can be used for mapping genetic networks in the cells. On the basis of the current results and previous work they conclude that there is partial functional redundancy between the transcription factors regulating the cell cycle, with the exception of Mcm1 and Ndd1, which are essential for yeast survival.

\section{Reporter's comments}


This paper is important for two reasons. First, it describes an innovative method of direct global analysis of transcriptional regulation. Second, it is a first step towards a map of the cell-cycle control network. There is, however, a limitation in the use of this method in organisms such as human or mouse because of incomplete genome sequencing and annotation. As a result, not all intergenic sequences can be identified and only limited pathways can be analyzed. Finally, the authors suggest that there is functional redundancy between the transcription factors. It would be interesting to analyze transcriptional regulation in mutants to identify which of the factors can interact to drive the cell cycle.

\section{Table of links}

Cell

Serial Regulation of Transcriptional Regulators in the Yeast Cell Cycle

\section{References}

1. Simon I, Barnett J, Hannett N, Harbison CT, Rinaldi NJ, Volkert TL, Wyrick JJ, Zeitlinger J, Gifford DK, Jaakkola TS, Young RA: Serial regulation of transcriptional regulators in the yeast cell cycle. Cell. 2001, 106: 697-708. 0092-1903 